\title{
PENGUNGKAPAN TANGGUNG JAWAB SOSIAL PERUSAHAANDALAM MENINGKATKAN PROFITABILITAS
}

\author{
Ardianti ${ }^{1}$ \\ Abid Ramadhan ${ }^{2}$ \\ ${ }^{1}$ Fakultas Ekonomi dan Bisnis, Universitas Muhammadiyah Palopo, Indonesia \\ ardiantiamiir21@gmail.com \\ ${ }^{2}$ Fakultas Ekonomi dan Bisnis, Universitas Muhammadiyah Palopo, Indonesia \\ abidramadhan8@gmail.com
}

\begin{abstract}
Corporate social responsibility or more popularly with the term corporate social responsibility is a concept in which a company cannot be separated from its relationship with stakeholders or stakeholders. This concept combines social and economic aspects which aim to help create prosperity for company stakeholders such as consumers, the environment and the surrounding community. The purpose of this study is to analyze and reveal the effect of CSR on profitability as calculated by Return on Assets in companies listed on the Jakarta Islamic Index (JII). model of research is quantitative in nature. Methods of data analysis in this study using simple linear regression analysis method. The study population came from companies registered in JII with an observation period from 2013-2018 with the annual report as a research study material. The results of the study showed that CSR had no effect on ROA.
\end{abstract}

Keywords: CSR, ROA, JII

\section{PENDAHULUAN}

Pada awalnya kegiatan sosial perusahaan banyak dilandasi oleh kegiatan yang bersifat filantropi yakni kedermawanan atau sikap peduli terhadap sosial yang dilakukan hanya sebatas sukarela atau sumbangan saja, akan tetapi saat ini sudah menjadi tanggung jawab sosial yang dilakukan oleh perusahaan untuk meningkatkan tingkat kepercayaan atas kehadiran perusahaan di tengah-tengah kehidupan masyarakat sehingga kepercayaan itu akan dapat memengaruhi tingkat kinerja perusahaan dalam menghasilkan laba.
Pada dasarnya $C S R$ merupakankegiatan pilantrophy yang dilaksanakan oleh perusahaan dalam rangka menanggapi isu sosial yang berada di masyarakat dan lingkungan tempat perusahaan tersebut didirikan, bertujuan untuk meningkatkan kesejahteraan masyarakat dan juga mengoptimalkan nilai perusahaan serta kinerja keuangan perusahaan (profitabilitas) di mata pemegang saham. Namun terdapat beberapa konfik yang melibatkan perusahaan dengan masyarakat diantaranya: 
Tabel 1

Permasalahan CSR

\begin{tabular}{|c|c|}
\hline No & Permasalahan \\
\hline 1 & $\begin{array}{l}\text { Pencemaran lingkungan yang dilakukan oleh PT kamarga kurnia textile } \\
\text { industri (KKTI) di kawasan sungai citarum yang mengakibatkan ganti rugi } \\
\text { materill Rp. } 16,263 \text { milyar. }{ }^{1}\end{array}$ \\
\hline 2 & $\begin{array}{l}\text { Pencemaran laut yang dilakukan oleh PT Nagamas Palmoil Lestari di laut } \\
\text { dumai yang berdampak pada rusaknya ekosistem laut. Denda materill 3- } 10 \\
\text { Milyar. }\end{array}$ \\
\hline 3 & $\begin{array}{l}\text { Pencemaran sungai oleh pabrik tekstil indobarat di bantaran sungai kalimati } \\
\text { dijatuhi hukuman denda } 2 \text { Milyar dan kewajiban membersihkan muara sungai }_{\text {tersebut. }}{ }^{\text {. }}\end{array}$ \\
\hline \multicolumn{2}{|c|}{$\begin{array}{l}\text { https://www.mongabay.co.id/2020/03/04/dua-perusahaan-cemari-das-citarum-kena- } \\
\text { hukum-rp1626-miliar/ }^{1}\end{array}$} \\
\hline \multicolumn{2}{|r|}{ https://cintalingkunganindustri.weebly.com/kasus-pencemaran-limbah-industri.html ${ }^{2}$} \\
\hline
\end{tabular}

Kasus pencemaran diatas merupakan bagian terkecil dari banyaknya kasuskasus yang terjadi di masyarakat hingga berdampak pada pencemaran lingkungan, ketidakpercayaan masyarakat hingga kerugian perusahaan untuk membayar denda.

Pengungkapan CSR merupakan kewajiban yang harus dilakukan berdasarkan Undang-Undang No. 40 Tahun 2017. Sehingga pembangunan dan kemajuan negara bukan lagi bergantung sepenuhnya kepada pemerintah tetapi perusahaanperusahaan juga harus turut andil dalam mewujudkan kesejahteraan masyarakat.

Perusahaan yang bergerak dibidang industri harus selalu memperhatikan faktor lingkungan dalam melakukan kegiatan operasionalnya, sehingga dapat mendorong pertumbuhan ekonomi yang sehat.Gagasan inilah yang menghasilkan keputusan pemerintah untuk menerbitkan Undang-undang tentang tanggung jawab perusahaan kepada stakeholders dengan menyertakan laporan CSR di annual report atau laporan tahunan, khususnya perusahan yang bersinggungan langsung dengan lingkungan (Chandra Sari \& Farah Azizah, 2016).

Pelaksanaan CSR dapat membantu perusahaan untuk mewujudkan tujuan perusahaan untuk menghasilkan kinerja keuangan yang baik yang dapat diukur berdasarkankemampuan perusahaan menghasilkan keuntungan/laba.

Menurut Harrison (2012) dalam Salina \& Kartikasari (2017), Return on assets (ROA) merupakan ukuran tingkat keberhasilan suatu perusahaan menggunakan asetnya untuk menghasilkan keuntungan. Semakin 
tinggi nilai dari ROA makan semakin efesien perusahaan dalam menggunakan asetnya.

Beberapa penelitian sebelumnya telah meneliti dampak tanggung jawab sosial perusahaan yang diukur dengan tingkat keuntungan terhadap kinerja profitabilitas dijadikan sebagai bahan komplementer dan pertimbangan dalam penelitian ini. Penelitian yang dilakukan oleh Celvin \& Gaol (2015), Salina\& Kartikasari(2017), dan Sucipto \& Syahputra (2016) menyatakan bahwa CSR tidak berdampak pada profitabilitas perusahaan baik yang diwakili oleh NPM dan ROA.

Penelitian yang dilakukan oleh Puspitaningtyas et al. (2018), Nurwahidah (2016), Rosdwianti et al. (2016) menyatakan bahwa berdasarkan hasil pengujian terhadap hipotesis yang diajukan maka para peneliti menemukan bahwa tanggung jawab sosial perusahaan (CSR) memiliki pengaruh yang signifikan terhadap return on asset (ROA).

Berdasarkan artikel hukum Online.com (2014) dijelaskan bahwa belum semua perusahaan yang ada di Indonesia menjalankan pengungkapan CSR dengan baik, padahal perusahaan tersebut memiliki kemampuan untuk menjalankan kewajibannya, hal ini di buktikan dari sebuah data Corporate Forum for Community Development yang mengatakan bahwa hanya 253 perusahaan yang terdaftar sebagai anggota forum tersebut. Padahal jika dilihat dari regulasi yang telah disahkan, perusahaan yang beroperasi di indonesia diwajibkan untuk mengungkapkan laporan CSRnya.

Dari beberapa kasus permasalahan CSR dan adanya perbedaan hasil penelitian terdahulu, maka penulis tertarik untuk mengangkat judul "Pengungkapan Corporate Social Responsibility terhadap Return On Asset".

\section{LANDASAN TEORI}

\section{Stakeholder Theory}

Teori ini berpendapat bahwa perusahaan dalam melakukan operasi bukan hanya untuk kepentingan sendiri namun dituntut untuk memberikan manfaat untuk para pemangku kepentinga (stakeholders) yang merasakan manfaat dan dampak dari operasi perusahaan. Kehadiran perusahaan ditengah masyarakat sangat dipengaruhi oleh dukungan stakeholders yang merasakan efek dari kehadiran perusahaan tersebut.

Keseimbangan hubungan perusahaan dengan stakeholders harus ditopang dengan tanggung jawab perusahaan atas aktivitas operasi yang melibatkan lingkungan sekitar sehingga perusahan mampu beraktivitas dengan 
jangka panjang dan tentunya dapat memaksimalkan tingkat profitnya.

Wahyudi \& Azheri (2008), menjelaskan bahwa CSRmerupakan komitmen perusahaan sebagai upaya untuk memenuhi kewajiban atas pemgabilan kebijakan dengan memperhatikan kepentingan stakholders dan keberlangsungan lingkungan hidup yang berlandaskan pada ketentuan hukum yang berlaku.

Pernyataan ini sejalan dengan konsep teori stakeholder bahwa setiap aktivitas dan pengambilan keputusan perusahaan haruslah memperhatikan dan memberi manfaat bagi para stakeholder perusahaan yang nantinya akan meningkatkan nilai perusahaan sebagai dampak dari aktivitas operasi yang dilakukan serta meminimalisir kerugiankerugian yang terjadi.

\section{Corporate Social Responsibility}

Tanggung jawab sosial merupakan komitmen bisnis perusahaan yang akan berkontribusi pada pembangunan ekonomi melalui kerjasama dengan masyarakat, komunitas peduli lingkungan dan sosial untuk meningkatkan taraf hidup yang lebih baik bagi pelaku bisnis dan pembangunan nasional (Laely, 2020)

Berdasarkan penelitian yang dilakukan oleh Laely (2020) bahwa undang-undang penanaman modal yang dijadikan sebagai rujukan untuk mewajibkan tanggung jawab sosial dalam "RUU Perseroan Terbatas" yang ditafsirkan pada pasal 15 huruf B, mengartikan bahwa tanggung jawab sosial perusahaan adalah "tanggung jawab yang melekat pada perusahaan untuk menciptakan keserasian, keseimbangan dan kesesuaian lingkungan, nilai, norma dan budaya masyarat setempat" Praktik CSR haruslah dilaksanakan berdasarkan tanggung jawab etika secara Islami, yakni berlandaskan pada Al-quran dan hadits untuk tujuan menciptakan kebajikan seperti zakat, infaq, sedekah, dan wakaf, serta mengedepankan nilai kedermawanan dan ketulusan hati.

Secara sistematis pada penelitian yang dilakukan oleh Ramadhan (2019) CSR dapat diukur dengan menggunakan indikator pengukuran GRI-G4 yang diresmikan pada tanggal 22 mei 2013 di amsterdam belanda. Indikator pengukuran GRI-G4 terdiri atas bidang economic, human right, environment, labour practices, society and product responsibility.

GRI memelopori pengembangan kerangka pelaporan keberlanjutan yang komprehensif, yang digunakan secara luas di seluruh dunia. Laporan tersebut berisi informasi tentang perusahaan atau organisasi yang melaporkan dampak ekonomi, lingkungan, dan sosial. Laporan tersebut juga memberikan 
informasi tentang nilai-nilai organisasi dan model tata kelola, dan menunjukkan hubungan antara strategi dan komitmen terhadap ekonomi yang berkelanjutan (Chandra Sari \& Farah Azizah, 2016).

Pada dasarnya item CSR dapat dihitung dengan memberikan nilai 1 jika setiap item CSR diungkapkan dalam laporan tahunan perusahaan dan 0 jika tidak diungkapkan (Haniffa, 2002). Rumus:

Keterangan:

$$
C S R I j=\frac{\Sigma \mathrm{X} \mathrm{ij}}{N j}
$$

$$
\begin{aligned}
& \text { CSRI j }= \text { CSR index disetiap } \\
& \text { Perusahaan } \mathrm{j} \\
& \Sigma \mathrm{xij}= \text { jumlah item yang } \\
& \text { diungkapkan } \\
& \mathrm{Nj}= \text { jumlah item perusahaan } \mathrm{j}, \\
& \mathrm{Nj} \leq 149
\end{aligned}
$$

\section{Profitabilitas}

Septiana (2012) menjelaskan bahwa profitabilitas merupakan kemampuan perusahaan untuk menghasilkan keuntungan bersih dari aktivitas operasionalnya. Rasio ini digunakan untuk mengukur efektivitas manajemen secara komprehensif dengan melihat besar kecilnya tingkat keuntungan yang diperoleh. Semakin baik rasio keuangan yang ditunjukkan perusahaan maka semakin baik pula gambaran keuntungannya (Nurarif \& Kusuma, 2013).

\section{Return On Asset}

Return On Asset adalah salah satu jenis rasio tingkat keuntungan yang digunakan untuk mengukur efektivitas penggunaan total aset perusahaan untuk menghasilkan keuntungan (Husnan, 2013). ROA adalah rasio yang yang sering digunakan untuk megukur perolehan laba atau keuntungan dari setiap asset yang digunakan. Informasi mengenai keuntungan yang diperoleh perusahaan mampu menilai keberhasilan atau kegagalan bisnis perusahaan dalam tujuan usaha yang telah ditetapkan. Semakin baik nilai ROA maka menunjukkan hasil efesien perusahaan dalam mengelola aset yang digunakan untuk menghasilkan keuntungan. Secara sistematis Return on Asset (ROA) dapat dirumuskan sebagai berikut:

$$
\text { ROA }=\frac{\text { Laba Bersih Setelah Pajak }}{\text { Totl aktiva }} \times 100 \%
$$

Sumber: (Syamsuddin, 2009)

\section{METODE PENELITIAN}

Penelitian ini bersifat kuantitatif yang berdasarkan pada perusahaan yang terdaftar di JII periode 2013-2018. Metode analisis menggunakan linear sederhana. Populasi penelitian berjumlah 180 perusahaan namun yang memenuhi syarat untuk diteliti dan dijadikan sampel penelitian yakni berjumlah 72 perusahaan yang dipilih berdasarkan kriteria yang ditentukan (purposive sampling). 


\section{HASIL PENELITIAN}

Tabel 1. Hasil Uji Signifikan Parsial (t) Profitabilitas

\section{Coefficients $^{\mathrm{a}}$}

\begin{tabular}{|c|c|c|c|c|c|}
\hline \multirow[t]{2}{*}{ Model } & \multicolumn{2}{|c|}{$\begin{array}{c}\text { Unstandardized } \\
\text { Coefficients }\end{array}$} & $\begin{array}{l}\text { Standardized } \\
\text { Coefficients }\end{array}$ & \multirow[t]{2}{*}{$\mathrm{t}$} & \multirow[t]{2}{*}{ sig } \\
\hline & B & std. error & beta & & \\
\hline (constant) & , 159 & ,091 & & 1,754 &, 084 \\
\hline 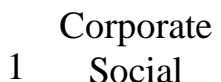 & & & & & \\
\hline $\begin{array}{l}\text { Responsibi } \\
\text { lity }\end{array}$ &,- 052 & 238 &,- 026 &,- 221 & ,826 \\
\hline
\end{tabular}

a. Dependent Variable: profitabilitas

Sumber: Data diolah, 2020

Berdasarkan tabel 1 diperoleh model persamaan regresi $\mathrm{Y}=0,159$ $0,052 \mathrm{X}_{1}$. Menunjukkan pengaruh CSR terhadap profitabilitas dalam hal ini ROA. Hasilnya koefisien regresi $-0,052$ dengan $t_{\text {hitung }}$ sebesar $-0,221$ dan $p$ sebesar 0,826 ( $\mathrm{p}>0,05)$. Berdasarkan output di atas nilai signifikan $>=0,05$ Maka hasilnya adalah $H_{0}$ ditolak yang artinya CSR tidak berpengaruh signifikan terhadap profitabilitas (ROA) diterima.

\section{PEMBAHASAN}

\section{Pengaruh CSR Terhadap ROA}

Hipotesis menyatakan bahwa CSR memiliki pengaruh terhadap ROA. Namun, berdasarkan hasil pengujian menggunakan Uji Signifikan parsial menggambarkan bahwa CSR tidak memiliki pengaruh terhadap ROA.

Hal ini tidak sejalan dengan teori stakeholders yang menyatakan bahwa dukungan stakeholders perusahaan akan berdampak positif bagi perusahaan yaitu meningkatkan pangsa pasar dan pertumbuhan penjualan.Dengan mengungkapkan CSR, perusahaan akan mendapatkan citra yang baik dimata masyarakat karena keberpihakannya kepada lingkungan dan masyarakat sekitar. Namun pengungkapan CSR belum sepenuhnya menjamin profitabilitas perusahaan akan meningkat.

Hasil penelitian ini sejalan dengan penelitian yang dilakukan oleh Salina\& Kartikasari(2017), yang menyatakan bahwaCSR tidak memiliki pengaruh terhadapprofitabilitas(ROA). Kemudian berdasarkan uji simultan dan uji parsial yang dilakukan oleh Sucipto \& Syahputra (2016) CSR yang meliputi biaya bina lingkungan, biaya kemitraan, biaya kesejahteraan karyawan tidak memiliki pengaruh terhadap profitabilitas (ROA).

Namun tidak sesuai dengan penelitian Chandra Sari \& Farah Azizah 
(2019),Puspitaningtyas et al. (2018), NurwahidSah, (2016),Rosdwianti et al. (2016)yang mengemukakan bahwa CSR memiliki pengaruh terhadap ROA. Perbedaan hasil ini mungkin saja disebabkan oleh sampel perusahaan yang diteliti dan lamanya tahun periode penelitian.

\section{SIMPULAN DAN SARAN}

\section{Simpulan}

Berdasarkan penelitian dan pembahasan di atas, penulis dapat menyimpulkan bahwa pengungkapan CSR perusahaan berdasarkan pada perusahaan yang terdaftar di Jakarta Islamic Index (JII) selama tahun 20152018 tidak memiliki pengaruh terhadap profitabilitas.

\section{Saran}

1. Bagi perusahaan, peneliti menyarankan untuk senantiasa membenahi pengungkapan CSR perusahaan agar kiranya dampak dari pengungkapan tersebut dapat lebih dirasakan oleh perusahaan yaitu mampu meningkatkan kinerja keuangan serta nilai perusahaan. Selain itu, peneliti menyarankan kepada perusahaan untuk senantiasa melakukan perencanaan yang efektif dan efesien melalui kegiatan CSR serta selalu menjaga konsistensi dalam menghasilkan laba perusahaan.
2. Bagi peneliti selanjutnya, disarankan untuk menambah variabel lainnya yang belum diteliti dalam penelitian ini dan memperbanyak jumlah sampel penelitian serta memperbanyak membaca referensi seperti buku dan penelitian terdahulu.

\section{DAFTAR PUSTAKA}

(Nurarif \& Kusuma, 2016). (2013). Journal of Chemical Information and Modeling, 53(9), 1689-1699. https://doi.org/10.1017/CBO97811 07415324.004

Celvin, H., \& Gaol, R. L. (2015). Pengaruh Pengungkapan Coorporate Social Responsibility (Csr) Terhadap Profitabilitas Perusahaan Pertambangan Yang Terdaftar Di Bursa Efek Indonesia.1(2), 139-166.

Chandra Sari, K., \& Farah Azizah, D. (2016). Pengaruh Corporate Social Responsibility (Csr) Terhadap Kinerja Keuangan Perusahaan Pertambangan Yang Terdaftar Di Bursa Efek Indonesia. Jurnal Manajemen Update, 3(Vol 1, No 1 (2012): Jurnal Mahasiswa Manajemen), 19-32. http://jurnal.untan.ac.id/index.php/ ejmfe/article/view/737

Haniffa, R. (2002). Social Reporting Disclosure: An Islamic Perspective.Indonesian Management \& Accounting Research. Vol.1 No.2 July 2002 pp. $128-146$.

Harrison, W. (2012). T. Jr.et.al Akuntansi Keuangan: International Finantial Reporting Standars (G. Gania (ed.)). Erlangga.

Hukum Online.com. (2014.). $C F C D_{-}$ Belum Semua Perusahaan Jalankan CSR - hukumonline. 
Husnan, S. (2013). Manajemen Keuangan Edisi Keempat. BPFE.

Laely, N. (2020). Bab II KAJIAN PUSTAKA 14082016. 2007, 5-14.

Nurwahidah. (2016). Pengaruh Penerapan Corporate Social Responsibility (CSR) terhadap Profitabilitas pada Perusahaan Pertambangan yang tercatat di Bursa Efek Indonesia (BEI). 6, 1939.

Puspitaningtyas, Z., Lestari, O. D., \& Prakoso, A. (2018). Penerapan Corporate Social Responsibility Terhadap Profitabilitas Perusahaan Barang Konsumsi yang Terdaftar di Bursa Efek Indonesia 20122016. Ekspektra: Jurnal Bisnis dan Manajemen, 2(1), 89. https://doi.org/10.25139/ekt.v2i1.7 00

Ramadhan, A. (2019). Pengaruh Ukuran Perusahaan, Profitabilitas Dan Kinerja Lingkungan Terhadap Corporate Social Responsibility Disclosure. SSRN Electronic Journal, 5(564), 1-19. https://doi.org/10.4324/978131585 3178

Rosdwianti, M. K., AR, M. D., \& Z.A, Z. (2016). Pengaruh Corporate Social Responsibility Terhadap Profitabilitas Perusahaan (Studi Empiris pada Perusahaan Sektor Industri Barang Konsumsi yang Terdaftar di Bursa Efek Indonesia
Tahun 2010-2013). Nominal, Barometer Riset Akuntansi dan Manajemen, 4(2), 16-22. https://doi.org/10.21831/nominal.v $4 \mathrm{i} 2.8002$

Salina, N., \&Kartikasari, D. (2017). Pengaruh Pengungkapan Program Corporate Social Responsibility Terhadap Profitabilitas Perusahaan. Jurnal Akuntansi, Ekonomi dan Manajemen Bisnis, 5(2), 193-203.

Septiana, R. A. (2012). Pengaruh Implementasi Corporate Social Responsibility Terhadap Profitabilitas Perusahaan. Jurnal Pendidikan Ekonomi \& Bisnis, 4(2), 71-84. http://ejournal.unri.ac.id/index.php/ JPEB/article/view/431/425

Sucipto, T. N., \& Syahputra, H. E. (2016). Pengaruh Corporate Social Resposibility ( $\mathrm{Csr}$ ) Terhadap Profitabilitas Pada Perusahaan Sektor Industri Barang. 1(1), 13-19.

Syamsuddin, L. (2009). Manajemen Keuangan Perusahaan, Konsep Aplikasi dalam: Perencanaan, Pengawasan, dan Pengambilan Keputusan. PT Raja Grafindo Persada.

Wahyudi, I., \& Azheri, B. (2008). Corporate Social Responsibility: Prinsip, Pengaturan dan Implementasi. In-Trans Publishing. 